\title{
Borders and Catastrophe: lessons from COVID-19 for the European Green Deal
}

\author{
Maren Klein
}

European Union Centre of Excellence at RMIT University maren.klein@rmit.edu.au

\section{Chloe Ward}

\section{European Union Centre of Excellence at RMIT University} chloe.ward.@rmit.edu.au

\section{Bradley Davison}

European Union Centre of Excellence at RMIT University s3604129@student.rmit.edu.au

\section{Sophie Di-Francesco Mayot}

European Union Centre of Excellence at RMIT University sophie.di.francesco.-.mayot@rmit.edu.au

\section{Debbi Long}

\author{
European Union Centre of Excellence at RMIT University \\ debbi.long@rmit.edu.au
}

\section{Campbell Hughes}

\section{European Union Centre of Excellence at RMIT University} s3645970@student.rmit.edu.au

\begin{abstract}
This article considers how the European Union and Member States' responses to the COVID-19 crisis in the first half of 2020 could inform climate action in Europe, and particularly the resumption of actions on the EGD. It first outlines the EU's public health and economic responses to COVID-19 and Europe's role in the global response to the pandemic. We find that, based on the challenges and successes of all these responses, a strong argument can be made for 'more Europe' - greater integration, and stronger EU-level institutions - to lead and govern the COVID-19 response. This has direct lessons for the governance and scope of future climate action.
\end{abstract}

Key words: European climate policy, COVID-19, climate change, European Union, public health

\section{Introduction}


Like the climate crisis, the COVID-19 pandemic transcends borders. Both also require concerted action at all levels of government. In December 2019, the incoming European Commission (EC) led by new President Ursula von der Leyen, announced the European Green Deal (EGD), a suite of actions at the European level designed to ensure that Europe meets the target of a 'carbon-neutral continent' by 2050. However, progress on instituting major measures announced in the EGD stalled, when the coronavirus crisis hit Europe in early 2020.

This article considers how the European Union and Member States' responses to the COVID-19 crisis in the first half of 2020 could inform climate action in Europe, and particularly the resumption of actions on the EGD. It first outlines the EU's public health and economic responses to COVID-19 and Europe's role in the global response to the pandemic. We find that, based on the challenges and successes of all these responses, a strong argument can be made for what we call 'more Europe' - greater integration, and stronger EU-level institutions - to lead and govern the COVID-19 response. This has direct lessons for the governance and scope of future climate action. Case studies of national responses to the pandemic contain lessons for a strong, coherent, radical European response to the climate crisis.

\section{The European Green Deal}

The announcement of the EGD in December 2019 marked the intersection of three major developments in Europe. Munta calls these 'problem, policy, and politics' (2020). In late 2019, the scale of the problem of climate change crashed in on policymakers and political leaders, with longstanding climate campaigners and a youth-led climate change movement winning a global media platform and a place at national and international forums with demands for serious action to reduce global carbon emissions. In Europe, momentum for a comprehensive climate policy had been building for at least a decade. The politics of the EC elections also favoured climate action, with von der Leyen winning the EC Presidency in part through undertakings to Green, Socialist, and Liberal MEPs on climate. Finally, with the retrenchment of the US from serious climate action under Donald Trump, a role has opened for the EU, the world's third-largest emitter, to take a leading global role in reducing carbon emissions.

A range of actions in the EGD, from incentivisation to compulsion, gives the EU new influence and powers over climate action in Europe and influence in the world. The EGD targets 50-55\% carbon emission reductions by 2030 and legislates a European 'Climate Law' that would enshrine the goal of a climate-neutral EU continent by 2050. Under the EGD, existing environmental policies will be integrated, with the aim of establishing a 'circular economy' and preserving ecosystem biodiversity. It also proposes a 'Just Transition Fund', to help carbon-dependent Member States transition to renewable energy sources and the renewable energy economy, while supporting living standards and livelihoods. Additionally, a 'Carbon Border Tax' is designed to protect European steel and other energy-intensive industries from cheaper competitors with lower climate change reduction policies (Guarascio \& Ekblom, 2019). European importers of these products/services will need to buy carbon allowances, similar to those under the European Emissions Trading System. This mechanism aims to ensure that European industries trying to lower their carbon emissions will remain competitive in global markets and are not punished for their efforts (Allan, 2019). 
At the time of writing, barely six months had passed since the EGD was first announced. Early appraisals of the merits of the EGD broadly fall into two camps. Assessments of it that focus on 'what is achievable' consider the EGD will be implemented, and generally approve of the plan. Assessments that focus on 'what is required' are much more critical of the EGD, considering its shortcomings and what an alternative plan should look like (Storm, 2020).

Public funding for EGD initiatives will come largely from existing EU funds, and the European Commission has promised to 'mobilize' private sector investment. Plans for funding the EGD have elicited strident criticism of the plan as, in prominent critics' words 'a colossal exercise in greenwashing', that offloads risk onto the public, and hides Europe's failure to withdraw completely from the fossil economy (quoted in Storm, 2020). Yet, as Storm points out, the failings of the EGD proposal should not be a barrier to thinking constructively about what it could become. Storm canvasses a range of alternative and more expansive funding sources and instruments, including a strengthened carbon tax, and a wealth tax as mooted by international economists. Such suggestions can be taken as provocations to think critically, and imaginatively, about corporate power and the priorities of public spending, in a world whose primary challenge to security and livelihoods is now, and will continue to be, climate change.

Even among those who support the EGD, there is hesitation that its execution will fail or the deal as it stands is not enough to meet the scale of the climate challenge. Storm argues that to achieve the 2030 target, greenhouse gas emissions in Europe would have to fall by as much as 5.2\% each year in the next decade - three times the rate from 1990-2020. This is a formidable task, 'Yet [it] still falls short of what is, according to climate science, needed to prevent the global mean temperature above the safe threshold of $1.5^{\circ}$ Celsius'. The Bruegel Institute estimates that 'even if the Commission succeeds in mobilising $€ 1$ trillion of investments over ten years, this would just represent a third of the additional investment needs associated with the European Green Deal' (2020). Responding to the announcement of the EGD, Mariana Mazzucato of the UCL Institute for Innovation in Public Policy recommended redesigning European financial instruments to enable innovative and socially directed investment and growth (Mazzucato, 2019).

The EGD also faced significant political challenges to its implementation in early 2020. Much of the early controversy centred on the Climate Law, which EC Vice President Frans Timmermans promised to introduce within 100 days of the EGD's announcement. Only two days after the EGD was announced, Poland declared it would opt-out of the 2050 climate neutrality objective (Rankin, 2019). At the end of January, Timmermans and the EC opened public debate about the Climate Law, aiming to have it in place by the UN Climate Conference, which was scheduled to be held in Glasgow late in 2020. The tight timeline, and the expectation that MEPs would be hit with requests from industrial sectors asking for special provisions under the Climate Law, were obvious impediments to its progress. Meanwhile, many saw securing the 2030 target as even more urgent than implementing the Climate Law (Simon, 2020). Even before the coronavirus hit Europe, opinion on the EGD was already polarised.

\section{The EU response to COVID-19}

One of the first actions taken in Europe in response to the COVID-19 pandemic aimed to improve coordination at the federal level within the EU. On January 28th the EU 
Council activated the EU integrated political crisis response mechanism (IPCR), which is intended to improve flexibility and the timeliness of crisis responses by instituting changes to information sharing among Member States, the EC and the European External Action Service (Goniewicz et al., 2020). However, as the following section makes clear, the EU's limited mandate on public health, political and economic debates about the scale and structure of financial recovery instruments, as well as Member States' political opportunism, complicate a 'European' response to COVID19.

\section{The public health response}

The EU has a limited mandate in public health in Europe. Under the Maastricht Treaty, its role is to support, complement, or supplement Member States' actions (European Commission, 2020a). The Lisbon Treaty upheld the principle of subsidiarity, which in the case of health leaves governance at Member State and provincial level, however allowed that the EU "may adopt incentives designed to protect and improve human health and in particular to combat the major cross-border health scourges, measures concerning monitoring, early warning of and combating serious cross-border threats to health" (Tsolova, 2010). COVID-19, of course, perfectly fits the description of a "serious cross-border threat to health". In practical terms, the limited EU health mandate meant that while it could facilitate or hinder flows of goods and services through Member States, its powers to direct public health responses were highly circumscribed.

This goes some way towards explaining the sluggishness and the limits of the EU's early response to the COVID-19 crisis. While COVID-19 was first identified in China in late 2019, by February 2020 the global epicentre of the pandemic had shifted to Europe. The EU was criticised in the first weeks of the pandemic crisis for moving too slowly, with Italy in particularly lamenting that the EU was "slow to help" (Boffey, 2020). The Centre for European Reform, meanwhile, observed that "national governments have taken centre stage during the crisis, while the EU's initial reaction was slow and rather haphazard" (Gostyńska-Jakubowska \& Scazzieri, 2020). As Long points out (2020), while some of these criticisms, especially of the flow of equipment (such as masks and ventilators) were valid, others involved areas that are outside the EU's mandate. For instance, the EU does not have the authority to enforce most of the COVID-19 responses recommended by WHO (WHO, 2020). Such responsibilities, specifically reporting of case incidences, responses to infection, and infection prevention and control, clearly lie at Member State level.

Yet EU responses to COVID-19 have also demonstrated the importance of coordination between public health authorities and governments. Long (2020) suggests that the EU's origin as economic union may have contributed to the initially low level of attention being paid to the recommendations of its own health bodies, including the ECDC (European Centre for Disease Control), resulting in slower responses in the areas it did have a mandate for. The ECDC was, however, responsive in compiling data and in increasing testing capability, both of which began in late January. Meanwhile, the flow of equipment and sharing of resources, which could have been facilitated centrally, was notably missing in the initial weeks of the pandemic. In March, the EC threatened Germany with infringement proceedings over its export ban on Personal Protective Equipment (PPE) (Bayer et. al., 2020), and France requisitioned production of face masks in early March (FRANCE 24, 2020). 
This culminated in the creation of the rescEU stockpile of medical equipment, a common reserve of key equipment including PPE, surgical masks, testing equipment and respirators, 90\% financed by the EC (EC, 2020). This was a practical demonstration of the benefits of organising a response at the EU level. It does not, however, amount to the accrual of new powers to the EU, or the assertion of those powers over Member States. As de Ruijter et al. note, this cooperation on procurement, distribution, and supply chain management is voluntary and contractual: 'Decisions regarding urgency and need are organised in a fully contractual manner, which means that they must be taken inter-governmentally' (2020). It is also ad hoc, and reactive, part of an unplanned emergency response rather than an organised emergency preparedness response. The lack of preparedness is noteworthy, given that both the WHO and CDC have had sophisticated guidelines for viral pandemic preparedness in place since 2009 .

The experience of COVID-19 informs a case made by public health practitioners, policymakers and scholars for a stronger role for the EU in public health. De Ruijter et al. (2020) argue for centralised control of medical countermeasures including procurement, stockpiling, and allocation of equipment and medicines. In the past, this has been inhibited by Member States' insistence on separating health law and EU internal market law. However, the Commission's re-reading of the 'proportionality principle' in light of COVID-19 implies that health may in future be considered an EU objective, overriding Member State concerns. Similarly, Costa-i-Font (2020), notes the relative weakness of the ECDC compared to international counterparts, particularly the American Centre for Disease Control (CDC), the discrepancies between Member State responses to COVID-19, and the retreat to national selfinterest in a time of crisis. Based on this she makes the case for creating a public health authority at the European level, 'as independent as the ECB ... with a clear mission and remit for global health'.

\section{The economic response to COVID-19}

From its beginnings, in Italy and Spain, the COVID-19 crisis threatened to reopen old divisions in the EU between the prosperous north and the poorer south. In March 2020, Italy, Spain, France, and six other Member States called for so-called 'corona bonds' to support their economic responses to COVID-19: this is a form of mutualised debt, issued by the European Investment Bank, which would be shared by all EU Member States (Euronews, 2020). The argument for corona bonds was based on equity and solidarity, with advocates pointing out that the hardest hit nations, through no fault of their own, faced a greater economic crisis than their northern European partners. However, richer, northern European nations, led by the Netherlands, opposed the measure on the basis that their funds should not be used to bolster another nation's response to the crisis. The Netherlands, and others, insisted on the use of the European Stability Mechanism (ESM) to finance recoveries.

Germany's resistance was decisive in ensuring corona bonds were dropped during negotiations of the 'Eurogroup' of EU Finance Ministers at the end of March. Instead several interim measures were announced on 9 April, ahead of work on a longer-term EU recovery fund. The interim measures included a European Investment Bank fund of $€ 200$ billion accessible to companies hit by the health crisis, and a $€ 100$ billion commitment from the EC towards jobless reinsurance. It also made loans of up to $2 \%$ 
of any Member State's economic output available under the ESM to cover emergency health costs.

Use of the ESM was always going to be a fraught and contested measure (Montani, 2020), because it evokes memories of the punitive regime of austerity forced on Greece during the Eurozone Crisis of 2010-2012. While it is unlikely that austerity economics would be considered as a tool in the COVID-19 recovery efforts, for Southern European Member States the EU's economic response is nonetheless a test of European solidarity and their own, national politics (Tooze, 2020). For example, if the Italian public perceives the EU as uncompromising, public opinion may shift to favour Prime Minister Conte's hard-line Eurosceptic rival, Matteo Salvini.

Eventually, both corona bonds and the ESM were side-lined, in favour of a $€ 750$ billion recovery fund announced in May 2020, called "Next Generation EU". The fund borrows from capital markets and includes both loans and grants (Politico, 2020). Pandemic recovery and climate action are being explicitly linked in this EU response, however climate initiatives had mixed fortunes in July negotiations over the final deal: $30 \%$ of the total budget package is earmarked for climate objectives. However, the EU's proposed €40 billion Just Transition Fund (Čavoški, 2020) was slashed to €10 billion (European Council, 2020).

\section{Pandemic as political opportunity-Hungary's approach}

Hungary's right-wing, nationalist government took an opportunity presented by the COVID-19 pandemic to consolidate authoritarian powers under President Viktor Orbán and the ruling Fidesz Party (Zerofsky, 2020). This continues a process underway since 2010, when Orbán tapped into popular resentment of austerity and growing inequality in the wake of the GFC, to win a landslide election on an antiestablishment, Eurosceptic, nationalist, and anti-IMF platform. His government still has a near unlimited ability to legislate, make constitutional amendments, and appoint a friendly judiciary. Orbán used these powers to transform the country into what has been described as "a political greenhouse for an odd kind of soft autocracy, combining crony capitalism and far-right rhetoric with a single-party political culture" (Kingsley, 2018).

Hungary, which closed its borders early and employed strict measures, seems to have had a relatively low number of COVID-19 infections compared to other EU Member States, with a reported 4347 cases, and 596 deaths as of Wednesday 22 July (Johns Hopkins University Centre for Systems Science and Engineering, 2020). This is likely due to rapidly deployed and strictly maintained lockdown measures that were gradually eased from early May. It must be noted however that the veracity of these figures remains unverified, among other reasons because of limited press freedom in Hungary and the threat of jail time for reporting on the virus that the government regards as misleading.

On 11 March 2020, Orbán's government declared a state of emergency, banning incoming travel from China, Italy, and Iran. Two weeks later the state of emergency was extended indefinitely with the passing of the "Draft Law on Protecting Against Coronavirus". The new law included a number of measures such as criminalising the spreading of "distorted truths" or breaking isolation orders. It also gave the Prime Minister new power to rule by decree (Serhan, 2020). 
These new powers were heavily criticised within and outside Hungary. They led to a group of thirteen national leaders from the European People's Party to call for Orbán's Fidesz party to be expelled from the centre-right political group (De La Baume, 2020; Walshe, 2020). Responding to the passage of these new powers into law, Von Der Leyen and the EC issued statements in defence of democracy, 'European values' and human rights, while not naming Hungary as the reason for these statements. The next day, 17 Member States issued a joint statement expressing their concern about issues 'arising from the adoption of certain emergency measures' (quoted in Flynn, 2020).

In May, the Hungarian Parliament voted to revoke the law, as promised by the government. However, human rights groups have warned that a second bill, introduced to Parliament at the same time, lays the basis for future rule by decree for an indefinite period of time (BBC, Hungarian Helsinki Committee, 2020). Through the course of the pandemic, the government has been both strategic and prolific in its use of the emergency powers, having issued over 100 decrees since April (Tanacs \& Huet, 2020; Zalan, 2020). These measures can be seen to solidify Orbán's position by removing legal impediments to his power, defunding his opposition, and empowering his allies. Orbán and the Fidesz Party have utilised the pandemic to their political advantage (Harangozó, 2020).

Member States and the EC's response to Orbán's actions have been criticised as ineffectual. Flynn argues that attempts to keep the peace with Hungary undermine EU integration (2020): 'this apparent reluctance of European heads of state and government to 'interfere' in another's 'domestic' affairs is a relic of a bygone age, a time when we really could draw such bright lines between the "national and the "European". Flynn counsels a strong, political counter-move by Europe: 'Remedying the authoritarian drift in the Union requires concerted political action, both within and between Member States'.

\section{Europe in the world}

The EU and Member States have demonstrated greater unity in their efforts in the global arena in response to the global COVID-19 pandemic. On 8 April, with a number of Member States still impacted severely by the virus, the EU resolved to become involved in fostering a coordinated multilateral response by leading efforts in the $\mathrm{G} 7$ and G2O in conjunction with the United Nations, the World Bank, the IMF and other multilateral actors, the so-called "Team Europe" approach (European Commission, $2020 b, 2020 c$ ). This initiative aims to support partner countries dealing with the pandemic through the (re)deployment of combined resources from the EU, its Member States, and financial institutions, in particular, the European Investment Bank and the European Bank for Reconstruction and Development. At the time of writing, the Team Europe package had a capacity of $€_{36}$ billion.

The approach has three priority areas: responding to the immediate health crisis and urgent humanitarian needs; strengthening health, water and sanitation systems; and mitigating the social and economic impacts of COVID-19. The Council of the European Union has also set out that these short-term and emergency responses must align with longer term measures to effectively address the structural impacts of the pandemic on partner countries effectively. It also intends that Recovery plans to be sustainable and in line with the 2030 Sustainable Development agenda and the EGD (Council of the European Union, 2020). 


\section{"More Europe" - but how?}

Written six months after COVID-19 emerged in Europe, assessments of how the pandemic will affect the implementation of the EGD are, of necessity speculative. For most, COVID-19 is a both a potential impediment and a potential catalyst for concerted climate action. Commentators highlight how the pandemic has thrown the EGD offcourse, losing valuable months of negotiations and implementation to the crisis. Europe's changed budgetary outlook might also disincentivise Member States to adopt the EGD. Equally, the reconstruction and recovery period might be seen as a 'reset' for Europe's fraught climate politics, and EGD actions might be built into the COVID-19 recovery effort (Mason, 2020; Munta, 2020; Elkerbout et. al., 2020).

The EC and some Member States are attempting to put the EGD and climate action at the centre of Europe's economic recovery from the COVID-19 pandemic. In mid-April the EC announced that some EGD initiatives would be delayed until 2021, however it retained the schedule for key priorities including the assessment of new emission reduction targets for 2030 (Siddi, 2020). Since then, Germany and France together sponsored proposals for the recovery that called for increases to the 2030 emissions target, reviews of state aid laws in light of climate policy, reforming and strengthening the EU Emissions Trading Scheme (ETS) and developing sectoral roadmaps for a green recovery (German Foreign Ministry, 2020).

\section{Institutions}

The future of state aid, in particular, could see changes in longstanding EU policy. The EC temporarily lifted strict state aid rules as part of its initial economic response to the COVID-19 crisis. Mason (2020) argues that ongoing reforms to state aid can be used to promote low-carbon strategies. Motta and Peitz give the airline industry and the automotive industry as example sectors this strategy might target (2020). They also suggest that the disbursement of recovery funds might be achieved and regulated by sector, rather than at Member State level. They depend on the principle of subsidiarity to justify such an EU-wide response, arguing that as environmental impacts of climate change are an externality affecting all of Europe, and one that cannot be dealt with effectively by individual Member States this is an appropriate use of EU powers.

This is one example of how EU responses to COVID-19 can be extended into an argument for 'more Europe, not less' in climate policy, which likewise targets an emergency that crosses national borders. However, the creation of new institutions and the reinterpretation of the EC's role is not a silver bullet for the challenges facing the EGD. Siddi highlights the legal competence of EU institutions, particularly the EC, as potential determinants of the EGD's future success: 'a protracted intra-EU turf war for competences, or a weak mandate for the institutions that should drive the Green Deal (particularly the Commission), could become significant obstacles to the implementation of the Green Deal' (2020).

\section{Politics}

It follows that a successful effort to influence recalcitrant Member States will be political, as much or more than it will be institutional. The examples of the negotiations over economic recovery and Hungary's recalcitrance and political opportunism demonstrate how, in a crisis, perceived national self-interest can be 
transacted through national and regional self-assertion at the expense of a European solution.

This requires moving past the sclerotic climate politics of the 2010-2019 period, which were overshadowed by the Eurozone crisis and Great Recession. Skovgaard views the failure of climate policy in this period through the lens of competing 'policy frames' (2014). Some Member States saw in the GFC and its aftermath an opportunity for 'green growth', marrying the transition to renewables and emissions reductions to economic growth. Others, notably Poland, and mostly heavily coal-dependent nations, saw the economic and policy choices facing Europe in this period as a 'trade off' between climate and growth.

The same two policy frames can be seen in initial responses to COVID-19, and the way governments and policymakers are linking this to climate action. In March, the Czech Premier Andrej Babiš explicitly used the language of a 'trade off', telling reporters that 'Europe should forget about the Green Deal now and focus on the coronavirus instead' (EURACTIV, 2020). Even after a U-turn in May which saw the Czech Republic back the new recovery fund, its draft statement supporting a green transition demanded Europe 'quantify the actual impact of the current pandemic on the economy of Member States and of the EU as a whole' before making any decisions about increasing the 2030 climate targets (EURACTIV, 2020).

The EU has lately approached this challenge through a new 'frame', that of 'Just Transition'. This means recognising the social costs of the transition to a green economy. It also recognises that these costs will be greater in coal-dependent economies. This frame can be occupied - arguably, cynically - by both advocates of green growth and those who fear a 'trade off'. The original EGD communication uses the language of 'just transition' and European solidarity in a plan 'leaving no one behind' (EC, 2019). In public statements at the initial December 2019 EGD negotiations, Babiš framed Czech demands for concessions on energy infrastructure, specifically arguing for a continuing role for nuclear power, in terms of the need for 'electricity for people, for firms, and heating'. Similarly, Orbán's Chief of Staff, Gergely Gulyas, said 'The 2050 climate goals cannot have the consequence of hiking the prices of food or energy' (Euronews, 2019).

As discussed above, the Just Transition Fund proposal presented to negotiations over Next Generation Europe in July was slashed. The EC also proposed that Member States must commit to the 2050 Climate Neutrality goal in order to access Just Transition Funds. Poland, now the only Member State which has yet to commit to the 2050 goal, has won a major concession at the negotiations. The final agreement stipulates that Member States who have not committed to the Climate Neutrality goal can only access $50 \%$ of their Just Transition entitlements.

\section{Finance}

In the debates and negotiations about Europe's economic recovery, several shibboleths of austerity economics have broken down, from the abandonment of the ESM, to the eventual isolation of the 'frugal four' (Austria, Denmark, Sweden and the Netherlands) who opposed grant payments at the Next Generation negotiations. In their place, debt has been accepted, and instituted as an instrument for recovery and economic development. So, too, the language and practice of European 'solidarity' informs 
recovery plans to a far greater extent than it did during the Eurozone crisis. The grants funded under Next Generation Europe are some distance from the original, corona bonds proposal, yet they also represented a significant development by putting in place common debt issuance in Europe.

Some commentators are calling for more fundamental, long-term reforms, that would institute closer integration and expansionary policy. The UCL Institute for Innovation and Public Purpose (IIPP) suggests that genuine solidarity requires more Europe and closer integration to create a de facto, central fiscal authority through common debt issuance (IIPP, 2020a). This logic is being applied to climate action funding: Guido Montani has suggested financing the EGD and other emissions reductions schemes through a reduction in global defence spending (Montani, 2020).

\section{"Team Europe" in the post-COVID world}

Europe has demonstrated a more unified approach on global actions, both in the COVID-19 pandemic and in environmental action. However, it still encounters a seriously challenging setting for future climate policy, in a time that may be marked by global downturn and growing antagonisms between the world's major powers. One direct result of the COVID-19 pandemic is a crisis in the oil sector and in global energy security. As the IIPP puts it, a 'post-COVID-19 world' may be characterised by 'dramatically lowered oil prices, which impairs the profitability of the entire industry, and raised significant energy security and geopolitical questions' (IIPP, 2020a).

Climate diplomacy, which presented itself as an opportunity and a motivation in the lead-up to the EGD's announcement, will undoubtedly be both more sensitive and more critical in the future. The EU has a long history of climate diplomacy, marked in the past 10 years particularly by its successes at the Paris climate negotiations in 2015, and its efforts working with third countries in coalition (Delreux \& Ohler, 2019). The strong commitments of the EGD exemplify its approach, which combines leadership by example, directionality, and ambition. However, the global implications of the EGD have been criticised, particularly the carbon border tax, which sceptics argue will be difficult to implement, and some have branded 'green protectionism' (Siddi, 2020).

Europe can nonetheless potentially act as both an influence and an actor in a future, global green transition. The IPP takes the EGD's plans to turn the European Investment Bank into the world's 'climate bank' as a model for other nations to follow in pursuing a 'green' recovery (2020b). It also emphasises that a just transition must include nations in the Global South, which should be supported through finance and supporting access to technology and capital goods. The "Team Europe" approach to the global COVID-19 response, by building in commitments to the Paris Climate Goals and the Sustainable Development Goals, is a step in this direction.

\section{Conclusion}

The EU is clearly committed to a 'green' recovery from the COVID-19 crisis, with the EGD at its centre. Innovative use of EU institutions, policy, and financial instruments in this crisis may have ongoing ramifications for thinking about implementation of the EGD. The Next Generation EU negotiations, particularly in embedding EGD initiatives in the European recovery and instituting new financial instruments, despite 
qualifications on its success, is an achievement that puts a Just Transition squarely in the frame for future policy developments.

Yet the fears that COVID-19 could derail serious climate action are not unfounded. Even before the arrival of the COVID-19 pandemic in Europe, there were serious doubts about whether the EGD was enough, or if its instruments were suitable for meeting the challenge of the climate crisis. These doubts have not gone away. The recalcitrance of coal-dependent Member States and resistance to EU-level influence and global political and economic upheaval will likely continue to present challenges to EU action on climate in the future, as it has done during the COVID-19 pandemic.

\section{References}

Allan, B. B. (2019, October 23). The E.U.'s looking at a 'carbon border tax.' What's a carbon border tax? The Washington Post.

https://www.washingtonpost.com/politics/2019/10/23/eus-looking-carbon-bordertax-whats-carbon-border-tax/

Bayer, L., Deutsch, J., Hanke Vela, J., \& Tamma, J. (2020, March 15). EU moves to limit exports of medical equipment outside the EU. Politico.

https://www.politico.eu/article/coronavirus-eu-limit-exports-medical-equipment/

Thorpe, N. (2020, June 16). Hungary votes to end Viktor Orban's emergency powers. BBC News. https://www.bbc.com/news/world-europe-53062177

Burns, C., Eckersley P., and Tobin, P. (2020). EU environmental policy in times of crisis. Journal of European Public Policy. 27:1, 1-19. DOI: 10.1080/13501763.2018.1561741

Čavoški, A. (2020): An ambitious and climate-focused Commission agenda for post COVID19 EU. Environmental Politics, 1-6.

https://doi.org/10.1080/09644016.2020.1784010

Claeys, G \& Tagliapetra, S. (2020, January 15). A trillion reasons to scrutinise the Green Deal Investment Plan. Bruegel Institute. https://www.bruegel.org/2020/01/a-trillionreasons-to-scrutinise-the-green-deal-investment-plan/

Costa-i-Font, J. (2020). The EU needs an independent public health authority to fight pandemics such as the COVID-19 crises. In A. Bénassy-Quéré \& B. Weder di Mauro (Eds.), Europe in the Time of Covid-19 (pp. 29-34). CEPR Press.

Council of the European Union. (2020, June 8). Council conclusions on Team Europe Global Response to COVID-19. Text of the Council conclusions.

https://www.consilium.europa.eu/media/44347/team-europe-ccs-200608.pdf

De Ruijter, A., Beetsma, R., Burgoon, B., Nicoli, F., \& Vandenbroucke, F. (2020). EU solidarity in fighting COVID-19: State of play, obstacles, citizens' attitudes, and ways forward. In A. Bénassy-Quéré \& B. Weder di Mauro (Eds.), Europe in the Time of Covid-19 (pp. 21-28). CEPR Press.

Delreux, T., \& Ohler, F. (2019). Climate Policy in European Union Politics. In Oxford Research Encyclopedia of Politics. Oxford University Press.

Elkerbout, M., Egenhofer, C., Nuñez Ferrer, J., Cătuţi, M., Kustova, I., \& Rizos, V. (2020). The European Green Deal after Corona: Implications for EU climate policy. CEPS Policy Insights. 
https://www.ceps.eu/download/publication/?id=26869\&pdf=PI2020o6 European-Green-Deal-after-Corona.pdf

EURACTIV.com \& AFP. (2020, March 17). Czech PM urges EU to ditch Green Deal amid virus. EURACTIV. https://www.euractiv.com/section/energyenvironment/news/czech-pm-urges-eu-to-ditch-green-deal-amid-virus/

European Commission. (2020a, March 19). Commission creates first ever rescEU stockpile of medical equipment.

https://ec.europa.eu/commission/presscorner/detail/en/ip $20 \quad 476$

European Commission, (2020b, April 8). Coronavirus: EU global response to fight the pandemic [Press Release].

https://ec.europa.eu/commission/presscorner/detail/en/IP 20604

European Commission, (2020c, April 8). EU global response to coronavirus: supporting our partner countries [Factsheet]. https://ec.europa.eu/commission/presscorner/detail/en/fs 20607

European Council, (2020, July 21), Special European Council, 17-21 July 2020. https://www.consilium.europa.eu/en/meetings/european-council/2020/07/17-21/

European Environment Agency, (2019). The European environment - state and outlook 2020: knowledge for a transition to a sustainable Europe. https://www.eea.europa.eu/soer/2020

European Union External Action Service, (2020, July 10). EU signs “Team Europe” grant agreements worth $€_{5.3}$ million to help tackle COVID-19 and its socio-economic consequences in Indonesia. https://eeas.europa.eu/headquarters/headquartershomepage/82674/eu-signs-\%E2\%80\%9Cteam-europe\%E2\%80\%9D-grant-agreementsworth-\%E2\%82\%AC53-million-help-tackle-covid-19-and-its-socio en

Flynn, T. (2020). Crisis, Opportunism, and Opportunity: How the Pandemic has Exacerbated Pre-existing Constitutional Tensions in the European Union. Covid-19, Law and Human Rights: Essex Dialogues. Ed. Ferstman, C and Fagan, A. School of Law and Human Rights Centre, University of Essex. 51-61.

FRANCE 24. (2020, March 3). Coronavirus: France to requisition face masks for use by health professionals, those infected. FRANCE 24. https://www.france24.com/en/20200303-coronavirus-france-to-requisition-facemasks-for-use-by-health-professionals-those-infected

German Foreign Ministry. (2020, May 18). French-German initiative for the European recovery from the coronavirus crisis. https://www.diplomatie.gouv.fr/en/countryfiles/germany/events/article/european-union-french-german-initiative-for-theeuropean-recovery-from-the

Goniewicz, C., Khorram-Manesh, A., Hertelendy, A.J., Goniewicz, M., Naylor, K., \& Burkle, F.M. (2020). Current Response and Management Decisions of the European Union to the COVID-19 Outbreak: A Review. Sustainability. 12(9), https://doi.org/10.3390/su12093838

Guarascio, F., \& Ekblom, J. (2019, December 10). Explainer: What an EU carbon border tax might look like and who would be hit. Reuters. https://www.reuters.com/article/usclimate-change-eu-carbontax-explainer/explainer-what-an-eu-carbon-border-taxmight-look-like-and-who-would-be-hit-idUSKBN1YE1C4 
Harangozó, A. (2020, June 16).With the Stroke of a Pen: Viktor Orbán and Emergency Rule-byDecree in Hungary. Visegrad Insight. https://visegradinsight.eu/hungary-emergencyrule-with-the-stroke-of-a-pen/

Hungarian Helsinki Committee, Hungarian Civil Liberties Union \& Amnesty International (2020, May 27). Never-Ending Story?. The Hungarian Helsinki Committee. https://www.helsinki.hu/en/never-ending-story/

Institute for Innovation and Public Purpose, (2020a). Inequality, unemployment and precarity. UCL IIPP COVID-19 Briefing Papers 02. https://www.ucl.ac.uk/bartlett/public-purpose/sites/publicpurpose/files/02 inequality unemployment and precarity 2.pdf

Institute for Innovation and Public Purpose, (2020b) A green economic renewal after the COVID-19 crisis. UCL IIPP COVID-19 Briefing Papers 04. https://www.ucl.ac.uk/bartlett/public-purpose/sites/public-purpose/files/o4 a green economic renewal after the covid-19 crisis 1.pdf

Jaeger, J. (2020, 2 June). Europe Charts a Course for Sustainable Recovery from COVID-19. World Resources Institute. https://www.wri.org/blog/2020/06/europe-chartscourse-sustainable-recovery-covid-19

Johns Hopkins University Centre for Systems Science and Engineering, (2020). Interactive Web-based dashboard to track COVID-19 in real time. https://coronavirus.jhu.edu/map.html

Kingsley, P. (2018, February 10). As West Fears the Rise of Autocrats, Hungary Shows What's Possible. The New York Times. https://www.nytimes.com/2018/02/10/world/europe/hungary-Orbán-democracyfar-right.html

Mason, A. (2020). Protecting Europe's Green Deal. International Development Research Network. https://www.idrneu.org/publications/protecting-europes-green-deal

Mazzucato, M. (2019, December 13). Europe's Green Deal could be the most important in a generation. UCL News. https://www.ucl.ac.uk/news/2019/dec/analysis-europesgreen-deal-could-be-most-important-generation

McCormick, J., \& Olsen, J. (2013). The European Union: politics and policies. Routledge.

Montani, G. (2020, January 16). The Green Deal and a disordered world. Social Europe. https://www.socialeurope.eu/the-green-deal-and-a-disordered-world

Motta, M. and Peitz, M. (2020). The EU Recovery fund: an opportunity for change. EU solidarity in fighting COVID-19: State of play, obstacles, citizens' attitudes, and ways forward. In A. Bénassy-Quéré \& B. Weder di Mauro (Eds.), Europe in the Time of Covid-19 (pp. 78-82). CEPR Press.

Munta, M. (2020). The European Green Deal: A game changer or simply a buzzword? Friedrich Ebert Stiftung.

Rankin, J. (2019, December 13). European Green Deal to press on despite Polish targets optout. Guardian. https://www.theguardian.com/environment/2019/dec/13/europeangreen-deal-to-press-ahead-despite-polish-targets-opt-out

Serhan, Y. (2020, April 2). The EU Watches as Hungary Kills Democracy. The Atlantic. https://www.theatlantic.com/international/archive/2020/04/europe-hungaryviktor-Orbán-coronavirus-covid19-democracy/609313/ 
Siddi, M. (2020). The European Green Deal: Assessing Its Current State and Future Implementation. FIIA Working Paper. Finnish Institute of International Affairs. https://www.fiia.fi/wp-content/uploads/2020/05/wp114 european-green-deal.pdf

Simon, F. (2020a, May 25) In political U-turn, Czechs back EU's green recovery plan. EURACTIV, https://www.euractiv.com/section/energy-environment/news/inpolitical-u-turn-czechs-back-eus-green-recovery-plan/

Simon, F. (2020b, January 29). Timmermans kicks off debate over landmark EU 'Climate Law', EURACTIV, https://www.euractiv.com/section/energyenvironment/news/timmermans-kicks-off-debate-over-landmark-eu-climate-law/

Skovgaard J. (2014). EU climate policy after the crisis. Environmental Politics. 23:1, 1-17. https://doi.org/10.1080/09644016.2013.818304

Steinebach Y. and Knill C. (2017). Still an entrepreneur? The changing role of the European Commission in EU environmental policymaking. Journal of European Public Policy . 24:3, 429-446. https://doi.org/10.1080/13501763.2016.1149207

Storm, S. (2020). The EU's Green Deal: Bismarck's 'what is possible' versus Thunberg's 'what is imperative'. Institute for New Economic Thinking Working Papers. https://www.ineteconomics.org/uploads/papers/WP 117-Storm-Green-Deal.pdf

Tanacs, G., \& Huet, N. (2020, June 16). Hungary ends emergency powers, but new law opens up potential to re-apply them. Euronews.

https://www.euronews.com/2020/06/16/hungary-debates-end-to-emergencypowers-but-new-law-opens-up-potential-to-re-apply-them

Tsolova, S. (2010). The Treaty of Lisbon and public health in the EU. European Journal of Public Health. 20:4, 475. https://doi.org/10.1093/eurpub/ckp235

Zalan, E. (2020, June 17). Critics warn of 'optical illusion', as Hungary decree-powers to end. EU Observer. https://euobserver.com/political/148667

Zerofsky, E. (2020, April 9). How Viktor Orbán Used the Coronavirus to Seize More Power. The New Yorker. https://www.newyorker.com/news/letter-from-europe/howviktor-Orbán-used-the-coronavirus-to-seize-more-power 
Copyright of Australian \& New Zealand Journal of European Studies is the property of Contemporary European Studies Association of Australia (CESAA) and its content may not be copied or emailed to multiple sites or posted to a listserv without the copyright holder's express written permission. However, users may print, download, or email articles for individual use. 